Buletin Ilmiah Mat. Stat. dan Terapannya (Bimaster)

Volume 08, No. 3 (2019), hal 421 - 428.

\title{
VERIFIKASI MODEL ARIMA PADA PERAMALAN JUMLAH KECELAKAAN LALU LINTAS KOTA PONTIANAK MENGGUNAKAN STATISTICAL PROCESS CONTROL
}

\author{
Canseria Yuli Ismayanti, Dadan Kusnandar, Nurfitri Imro'ah
}

\begin{abstract}
INTISARI
Peramalan adalah alat bantu yang penting dalam perencanaan yang efektif dan efisien. Salah satu langkah setelah peramalan adalah melakukan verifikasi model untuk memeriksa apakah model yang didapat sudah baik atau tidak untuk peramalan pada periode ke depan. Penelitian ini bertujuan untuk menerapkan metode Statistical Process Control (SPC) untuk memverifikasi model ARIMA terbaik dengan grafik pengendali Individual Moving Range (IMR). Grafik pengendali yang digunakan untuk menentukan perubahan dalam pola data menggunakan nilai errornya. Data yang digunakan dalam penelitian ini merupakan data bulanan jumlah kecelakaan lalu lintas Kota Pontianak dari tahun 2012 hingga tahun 2016 yang diperoleh dari Kepolisian Daerah Kalimantan Barat. Berdasarkan identifikasi model didapat model terbaik yaitu model ARIMA $(0,1,1)$ dengan hasil verifikasinya menunjukkan bahwa semua nilai error dalam keadaan terkendali. Perolehan nilai MAPE pada model ARIMA $(0,1,1)$ adalah 14,88\% dan BIC sebesar 4,23 artinya model ARIMA $(0,1,1)$ baik untuk meramalkan jumlah kecelakaan lalu lintas Kota Pontianak satu tahun ke depan.
\end{abstract}

Kata Kunci: Peramalan, SPC, grafik pengendali IMR

\section{PENDAHULUAN}

Kecelakaan lalu lintas merupakan kejadian dimana sebuah kendaraan mengalami benturan dengan kendaraan atau benda lainnya. Ada tiga faktor utama yang dapat menyebabkan kecelakaan lalu lintas yaitu manusia, kendaraan dan jalan. Selain ketiga faktor utama tersebut kecelakaan lalu lintas juga dapat dipengaruhi oleh faktor lingkungan yaitu cuaca.

Rata-rata jumlah kecelakaan lalu lintas dari tahun 2012 hingga tahun 2016 pada data Polda Kalimantan Barat khusus Kota Pontianak mencapai 43 kejadian setiap bulannya. Hal ini merupakan hal yang sangat memprihatinkan dan perlu mendapat perhatian serta penanganan yang serius. Sehingga Kepolisian Republik Indonesia (Polri) harus mengambil suatu kebijakan dalam menjalankan tugas, fungsi dan peranan Polri dalam memberikan pelayanan kepada masyarakat sebagai representasi atau perpanjangan tangan dari pemerintah. Upaya Polri untuk mengatasi hal tersebut diperlukan peramalan untuk memprediksi jumlah kecelakaan lalu lintas yang akan datang.

Peramalan adalah alat bantu yang penting dalam perencanaan yang efektif dan efisien [1]. Beberapa metode peramalan yang dapat digunakan untuk mengetahui tingkat jumlah kecelakaan lalu lintas yang akan datang ialah model Autoregressive (AR), Moving Average (MA), Autoregressive Moving Average (ARMA), dan Autoregressive Integrated Moving Average (ARIMA) [2]. Dasar pendekatan metode ini terdiri dari tiga tahap yaitu identifikasi model, penaksiran parameter dan diagnostic checking [1]. Langkah selanjutnya setelah peramalan adalah melakukan verifikasi model untuk melihat apakah model yang didapat sudah baik atau tidak untuk peramalan pada periode ke depan [3]. Metode yang digunakan untuk memverifikasi model ARIMA yaitu Statistical Process Control (SPC) dengan grafik pengendali.

Penelitian ini bertujuan untuk menerapkan metode peramalan ARIMA pada data jumlah kecelakaan lalu lintas di Kota Pontianak dan menerapkan metode SPC untuk memverifikasi model ARIMA terbaik dengan grafik pengendali Individual Moving Range (IMR) untuk peramalan periode ke depan. Langkah pertama dalam penelitian ini adalah uji stasioneritas data melalui grafik serta 
menggunakan uji Augmented Dickey-Fuller (ADF). Langkah kedua identifikasi model ARIMA melalui plot Autocorrelation Function (ACF) dan Partial Autocorrelation Function (PACF). Langkah ketiga mengestimasi parameter model ARIMA. Setelah itu pemilihan model terbaik berdasarkan nilai Bayesian Information Criterion (BIC) terkecil.

Langkah selanjutnya melakukan diagnostic checking untuk mengevaluasi ketepatan model ARIMA dengan uji Ljung-Box. Kemudian menghitung nilai error untuk membentuk grafik pengendali IMR. Selanjutnya memverifikasi model ARIMA terbaik dengan membuat grafik pengendali IMR dan menentukan batas kendali atas (UCL), garis tengah (CL), dan batas kendali bawah (LCL). Jika pada grafik kendali terdapat titik yang berada di luar UCL dan LCL maka grafik tersebut dikatakan tidak terkendali atau sebaliknya. Jika hasil pada grafik pengendali IMR menunjukkan proses sudah terkendali, artinya model ARIMA tersebut sudah baik untuk peramalan beberapa periode ke depan. Langkah terakhir adalah melakukan peramalan dengan model tersebut pada data jumlah kecelakaan lalu lintas Kota Pontianak.

\section{ANALISIS DERET WAKTU}

Deret waktu adalah rangkaian nilai pengamatan yang diamati secara beruntun selama kurun waktu tertentu, pada umumnya dalam interval-interval yang sama panjang. Kumpulan pengamatanpengamatan dalam deret waktu dinyatakan sebagai variabel yang sering dinotasikan sebagai $Z$. Datadata tersebut diamati pada waktu $t$, yaitu $t_{1}, t_{2}, \ldots, t_{n}$ dan variabel tersebut ditulis dalam notasi $Z_{t_{1}}, Z_{t_{2}}, \ldots, Z_{t_{n}}$ [4]. Peramalan deret waktu menggunakan pendekatan kuantitatif yaitu menggunakan data di masa lampau untuk meramalkan data di masa mendatang. Salah satu metode peramalan dalam deret waktu adalah model ARIMA yang telah dipelajari secara mendalam oleh George Box dan Gwilym Jenkins (1976). Model-model yang terdapat dalam metode peramalan ARIMA terdiri dari model AR dan MA. Model AR dengan ordo $p$ dinotasikan dengan AR $(p)$. Model MA dengan ordo $q$ dinotasikan dengan MA $(q)$. Gabungan kedua model tersebut dinotasikan dengan $\operatorname{ARMA}(p, q)$, sedangkan lambang $d$ hanya digunakan untuk data yang sudah melalui tahap pembedaan (differencing) yang dinotasikan dengan $\operatorname{ARIMA}(p, d, q)[2]$.

Data deret waktu dikatakan stasioner jika data tersebut berfluktuasi disekitar nilai rata-rata dan variansi yang relatif konstan sepanjang periode waktu. Kestasioneran dalam data deret waktu dapat dilakukan dengan menggunakan grafik dan uji ADF. Data deret waktu yang tidak stasioner pada umumnya dapat diatasi dengan proses differencing. Jika $Z_{1}, Z_{2}, \ldots, Z_{t}$ adalah suatu deret waktu maka operator Backshift didefinisikan sebagai berikut:

$$
B^{d}\left(Z_{t}\right)=Z_{t-d}
$$

dimana notasi $B$ (backshift) pada Persamaan (1) mempunyai pengaruh menggeser data sebanyak $d$ periode ke belakang [4].

\section{MODEL AUTOREGRESSIVE INTEGRATED MOVING AVERAGE (ARIMA)}

Autoregressive Integrated Moving Average adalah data deret waktu yang bersifat tidak stasioner atau disebut terintegrasi (integrated). Seringkali data deret waktu yang tidak stasioner pada orde pertama akan menjadi stasioner jika dilakukan differencing satu kali. Dengan demikian apabila menggunakan data deret waktu yang sudah dilakukan differencing sebanyak $d$ kali agar stasioner dan diterapkan pada model $\operatorname{ARIMA}(p, q)$, maka persamaannya akan menjadi $\operatorname{ARIMA}(p, d, q)$. Secara umum bentuk model ARIMA $(p, d, q)$ dituliskan sebagai berikut [2]:

$$
\phi(B)(1-B)^{d} Z_{t}=\mu^{\prime}+\theta(B) e_{t}
$$


dimana $\phi(B)$ adalah $\left(1-\phi_{1} B-\phi_{2} B^{2}-\ldots-\phi_{p} B^{p}\right)$ dan $\theta(B)$ adalah $\left(1-\theta_{1} B-\theta_{2} B^{2}-\ldots-\phi_{q} B^{q}\right)$.

\section{STATISTICAL PROCESS CONTROL (SPC)}

Pengendalian kualitas statistik adalah teknik yang digunakan untuk mengendalikan dan mengelola proses baik manufaktur maupun jasa melalui menggunakan metode statistik [5]. Pengendalian kualitas secara statistik dengan menggunakan SPC mempunyai tujuh alat bantu statistik utama [6], yaitu check sheet, histogram, grafik pengendali, diagram pareto, diagram sebab akibat, scatter diagram, dan diagram proses. Pada penelitian ini menggunakan salah satu alat bantu statistik yaitu grafik pengendali (control chart). Terdapat dua macam sifat data yang digunakan dalam SPC, yaitu sifat atribut dan sifat variabel. Sifat atribut adalah sifat komoditas yang tidak dapat diukur, melainkan dihitung sesuai dengan klasifikasi sesuai atau tidaknya dengan spesifikasi yang telah ditentukan. Istilah lainnya "cacat" dan "tidak cacat". Terdapat empat macam jenis grafik pengendali atribut yaitu grafik pengendali $p, n p, c$ dan $u$. Sedangkan sifat variabel adalah mutu yang dapat diukur dengan alat fisik, misalnya berat satuan, ukuran panjang, dan suhu.

\section{GRAFIK PENGENDALI VARIABEL}

Grafik pengendali variabel digunakan untuk prosedur pengendali yang lebih efisien dan memberikan informasi tentang penampilan proses yang lebih banyak daripada grafik pengendali atribut. Ada 3 macam jenis pada grafik pengendali variabel berdasarkan subgrupnya yaitu IMR, $\bar{x}-R$ dan $\bar{x}-S$.

Grafik pengendali digunakan untuk membantu mendeteksi adanya penyimpangan dengan cara menerapkan batas-batas kendali antara lain [5]:

1. Upper control limit / batas kendali atas (UCL).

Garis batas kendali atas untuk suatu penyimpangan dari kualitas statistik.

2. Central line / garis pusat atau garis tengah (CL).

Merupakan garis yang menunjukkan nilai rata-rata dari suatu data.

3. Lower control limit / batas kendali bawah (LCL).

Garis batas kendali bawah untuk suatu penyimpangan dari kualitas statistik.

\section{GRAFIK INDIVIDUAL MOVING RANGE (IMR)}

Grafik pengendali IMR digunakan ketika banyaknya variabel yang diamati adalah satu. Prosedur pengendalian kualitas statistik pada grafik pengendali IMR menggunakan rentang bergerak dari dua observasi yang berturutan untuk menaksir variabilitas proses. Langkah-langkah pembuatan grafik pengendali IMR adalah sebagai berikut [5]:

1. Grafik Individual Value

a. Hitung rata-rata

$$
\bar{x}=\frac{\sum_{i=1}^{n} x_{i}}{n}
$$

dimana $\bar{x}$ adalah rata-rata, $x_{i}$ adalah data atau sampel ke $i$, dan $n$ adalah banyaknya data.

b. Hitung batas kendali atas (UCL)

$$
U C L=\bar{x}+3 \frac{\overline{M R}}{d_{2}}
$$

dimana $\overline{M R}$ adalah rata-rata dari rentang bergerak atau $R_{i}$, dan $d_{2}$ adalah konstanta untuk $n=2$ yang nilainya 1,128 .

c. Hitung garis pusat / Center Line (CL) 
d. Hitung batas kendali bawah (LCL)

$$
C L=\bar{x}
$$

$$
L C L=\bar{x}-3 \frac{\overline{M R}}{d_{2}}
$$

2. Grafik Moving Range

a. Hitung rata-rata

$$
\overline{M R}=\frac{\sum_{i=1}^{n} R_{i}}{n}
$$

dimana $\overline{M R}$ adalah rata-rata, $R_{i}$ adalah data rentang bergerak ke $i$, dan $n$ adalah banyaknya data rentang bergerak.

b. Hitung batas kendali atas (UCL)

$$
U C L=D_{4} \times \overline{M R}
$$

dimana $D_{4}$ adalah faktor untuk membangun grafik pengendali variabel pada $n=2$ yang nilainya 3,267 .

c. Hitung garis pusat / Center Line (CL)

$$
C L=\overline{M R}
$$

d. Hitung batas kendali bawah (LCL)

$$
L C L=D_{3} \times \overline{M R}
$$

\section{IDENTIFIKASI DATA}

Data yang digunakan dalam penelitian ini adalah data jumlah kecelakaan lalu lintas Kota Pontianak dari bulan Januari tahun 2012 sampai bulan Desember tahun 2016. Berdasarkan Gambar (1a) grafik pada data jumlah kecelakaan lalu lintas terlihat belum stasioner karena titik-titik tersebut tidak befluktuasi di sekitar rata-rata dan variansi yang konstan. Karena data belum stasioner maka perlu dilakukan differencing. Hasilnya terlihat pada Gambar (1b) berikut:

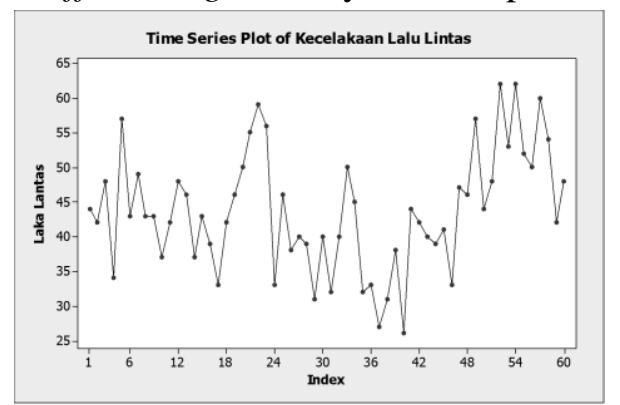

a) Grafik Data Asli

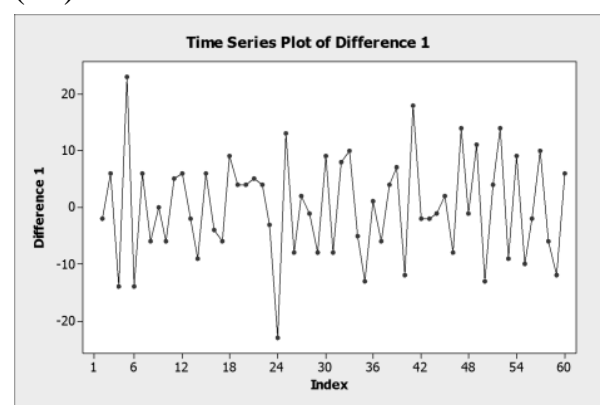

b) Grafik Differencing

\section{Gambar 1 Grafik Sebelum dan Setelah Differencing Jumlah Kecelakaan Lalu Lintas Kota Pontianak}

Berdasarkan Gambar (1b) grafik yang disajikan terlihat data sudah berfluktuasi di sekitar rata-rata dan variansi yang konstan sehingga data jumlah kecelakaan lalu lintas dikatakan stasioner. Hal ini juga terlihat dalam hasil uji ADF untuk melihat kestasioneran data pada rata-rata dan variansi. Hasil uji ADF dengan menggunakan software Eviews 6 disajikan pada Tabel 1. 
Tabel 1 Uji Stasioneritas menggunakan ADF

\begin{tabular}{lccc}
\hline \hline & & t-Statistic & P Value. \\
\hline \hline Augmented Dickey-Fuller test statistic & $-12,86$ & 0,00 \\
\hline Test critical values: & $1 \%$ level & $-3,55$ & \\
& $5 \%$ level & $-2,91$ & \\
& $10 \%$ level & $-2,60$ & \\
\hline \hline
\end{tabular}

Berdasarkan nilai $p$ value dari Tabel 1 terlihat bahwa nilai $p$ value $<\alpha(5 \%)$ sehingga dapat disimpulkan bahwa data jumlah kecelakaan lalu lintas sudah stasioner dalam rata-rata dan variansi, selanjutnya dibentuk plot ACF dan PACF. Plot ACF dan PACF disajikan pada Gambar 2 dengan bantuan software SPSS.

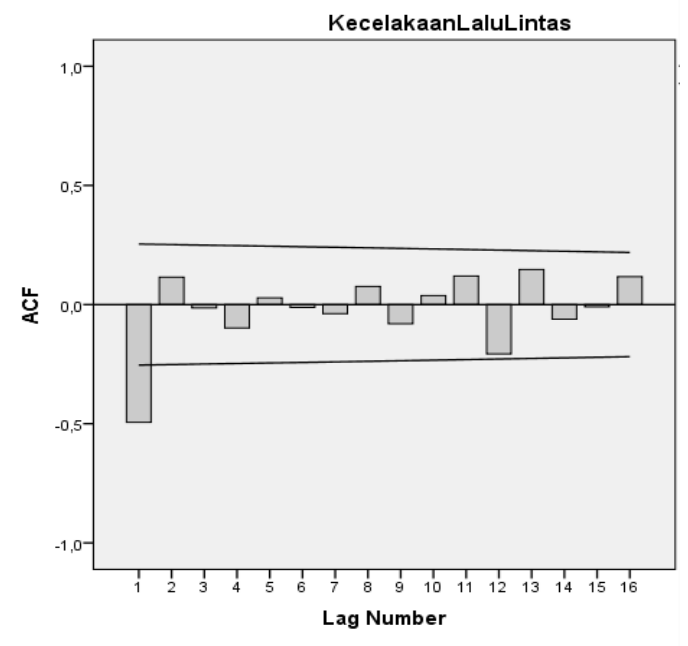

a.) Plot ACF

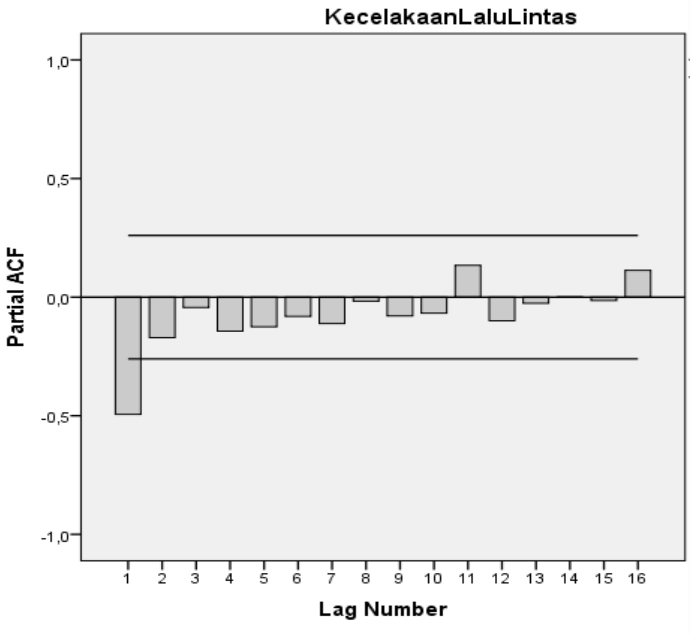

b.) Plot PACF

Gambar 2 Plot ACF dan PACF Jumlah Kecelakaan Lalu Lintas Kota Pontianak

Berdasarkan plot ACF dan PACF pada Gambar 2 terlihat bahwa plot ACF dan PACF cut off setelah lag 1 serta didapat beberapa kemungkinan model ARIMA yaitu ARIMA (1,1,1), ARIMA $(1,1,0)$, dan ARIMA $(0,1,1)$ dengan karakteristik sebagai berikut:

1. Model ARIMA $(1,1,1)$

Plot ACF dan PACF menunjukkan keduanya menurun secara eksponensial menuju nol atau keluar dari batas signifikansi sebanyak 1 dengan proses differencing sebanyak 1 kali.

2. Model ARIMA $(1,1,0)$

Plot ACF menunjukkan menurun secara eksponensial menuju nol yang berarti terjadi proses

AR dan ordo AR adalah 1 dengan proses differencing sebanyak satu kali.

3. Model ARIMA $(0,1,1)$

Plot PACF menunjukkan menurun secara eksponensial menuju nol yang berarti terjadi proses MA dan ordo MA adalah 1 dengan proses differencing sebanyak satu kali.

\section{ESTIMASI PARAMETER DAN PEMILIHAN MODEL TERBAIK}

Estimasi parameter model ARIMA $(1,1,1)$, ARIMA $(1,1,0)$, dan ARIMA $(0,1,1)$ dan pemilihan model terbaik menggunakan nilai Bayesian Information Criterion (BIC) dilakukan dengan bantuan software SPSS disajikan pada Tabel 2. 
Tabel 2 Estimasi Model ARIMA

\begin{tabular}{cccccc}
\hline Model & Parameter & $\begin{array}{c}\text { Parameter } \\
\text { Estimate }\end{array}$ & BIC & P Value & MAPE \\
\hline ARIMA (1,1,1) & Constant & 0,96 & & 0,81 & \\
& AR (1) & 0,12 & 4,32 & 0,96 & 14,88 \\
& Differencing & 1 & & 0,00 & \\
& MA(1) & 0,63 & & 0,95 & \\
\hline ARIMA (1,1,0) & Constant & 0,46 & & 0,00 & 14,58 \\
& AR(1) & $-0,49$ & 4,27 & & \\
& Differencing & 1 & & 0,81 & \\
ARIMA & Constant & 0,95 & $\mathbf{4 , 2 3}$ & & \\
$(0,1,1)$ & Differencing & 1 & & 0,00 & \\
& MA(1) & 0,62 & & & \\
\hline
\end{tabular}

Berdasarkan Tabel 2 didapat persamaan model ARIMA sebagai berikut:

1. Model ARIMA $(1,1,1)$

$$
Z_{t}=0,96+1,12 Z_{t-1}-0,12 Z_{t-2}+e_{t}-0,63 e_{t-1}
$$

2. Model ARIMA $(1,1,0)$

$$
Z_{t}=0,46-1,49 Z_{t-1}-0,49 Z_{t-2}+e_{t}
$$

3. Model ARIMA $(0,1,1)$

$$
Z_{t}=0,95+Z_{t-1}+e_{t}-0,62 e_{t-1}
$$

Nilai BIC terkecil dari tiga model tersebut adalah model ARIMA $(0,1,1)$ dan nilai MAPE pada model ARIMA $(0,1,1)$ adalah $14,88 \%$ sehingga model yang tepat untuk digunakan dalam penelitian ini adalah model Integrated Moving Average (IMA) dengan ordo MA(1) dan differencing sebanyak satu kali.

\section{DIAGNOSTIC CHECKING}

Diagnostic checking dengan menggunakan uji Ljung-Box dengan bantuan software SPSS disajikan pada Tabel 3.

Tabel 3 Diagnostic Checking

\begin{tabular}{cccc}
\hline Lag & Df & $\chi_{\text {Hitung }}^{2}$ & P-value \\
\hline 12 & 10 & 5,10 & 0,88 \\
24 & 22 & 15,30 & 0,85 \\
36 & 34 & 22,50 & 0,94 \\
48 & 46 & 31,80 & 0,95 \\
\hline
\end{tabular}

Berdasarkan Tabel 3 terlihat bahwa model ARIMA $(0,1,1)$ memiliki nilai $p$ value $\geq \alpha(5 \%)$ artinya model ARIMA $(0,1,1)$ adalah model terbaik. Model terbaik adalah model ARIMA $(0,1,1)$ sebagai berikut:

$$
Z_{t}=0,95+Z_{t-1}+e_{t}-0,62 e_{t-1}
$$

\section{VERIFIKASI MODEL ARIMA}

Berdasarkan model ARIMA yang didapat, selanjutnya dihitung nilai error dan rentang bergerak (moving range) pada data jumlah kecelakaan lalu lintas. Setelah itu ke tahap verifikasi model ARIMA $(0,1,1)$ dengan menggunakan grafik pengendali untuk melihat apakah model tersebut sudah terkendali ataupun tidak secara statistik. 
Penelitian ini menggunakan grafik pengendali IMR. Berikut nilai-nilai UCL, CL dan $L C L$ untuk membuat grafik pengendali IMR disajikan pada Tabel 4.

Tabel 4 Nilai UCL, CL dan LCL Grafik Pengendali IMR

\begin{tabular}{cccc}
\hline & UCL & CL & LCL \\
\hline Individual Value & 24,09 & $-0,00$ & $-24,09$ \\
Moving Range & 29,60 & 9,06 & 0,00 \\
\hline
\end{tabular}

Berdasarkan Tabel 4 diatas, selanjutnya dibentuk grafik pengendali IMR model ARIMA $(0,1,1)$ disajikan pada Gambar 3 dengan bantuan software Minitab:

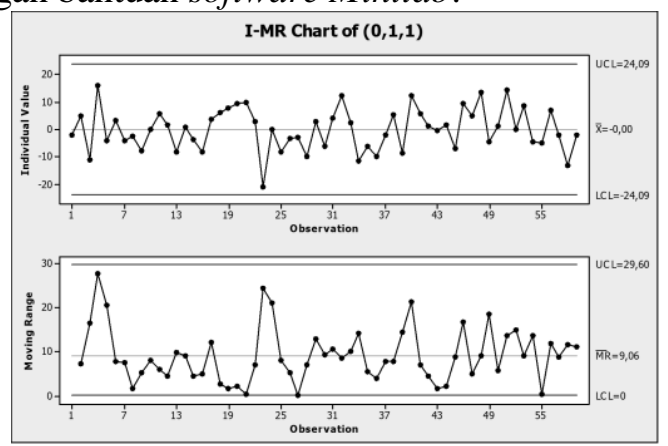

\section{Gambar 3 Grafik Pengendali IMR model ARIMA $(0,1,1)$}

Berdasarkan Gambar 3 menunjukkan semua nilai error pada grafik pengendali diatas dalam keadaan terkendali yang artinya tidak ada titik yang berada diluar batas UCL dan LCL. Hal ini menunjukkan bahwa model ARIMA $(0,1,1)$ adalah model yang baik untuk meramalkan jumlah kecelakaan lalu lintas di Kota Pontianak.

\section{PERAMALAN}

Berdasarkan hasil verifikasi dan nilai MAPE pada model ARIMA $(0,1,1)$ yang menunjukkan bahwa model ARIMA $(0,1,1)$ mempunyai kemampuan prediksi yang baik, maka model ARIMA $(0,1,1)$ dapat diterapkan pada data jumlah kecelakaan lalu lintas Kota Pontianak. Hasil peramalan data jumlah kecelakaan lalu lintas Kota Pontianak disajikan pada Tabel 5.

Tabel 5 Hasil Peramalan Jumlah Kecelakaan Lalu Lintas Kota Pontianak dengan Model ARIMA $(0,1,1)$

\begin{tabular}{cc}
\hline Bulan & Hasil Peramalan \\
\hline Januari & 49 \\
Februari & 49 \\
Maret & 49 \\
April & 49 \\
Mei & 49 \\
Juni & 49 \\
Juli & 50 \\
Agustus & 50 \\
September & 50 \\
Oktober & 50 \\
November & 50 \\
Desember & 51
\end{tabular}

Proses peramalan jumlah kecelakaan lalu lintas di Kota Pontianak periode bulan Januari sampai bulan Desember tahun 2017 dengan menggunakan model ARIMA $(0,1,1)$ dinilai baik, karena hasil peramalan yang diperoleh mendekati data aslinya. Hal ini dapat dilihat pada Gambar 4 di bawah ini: 


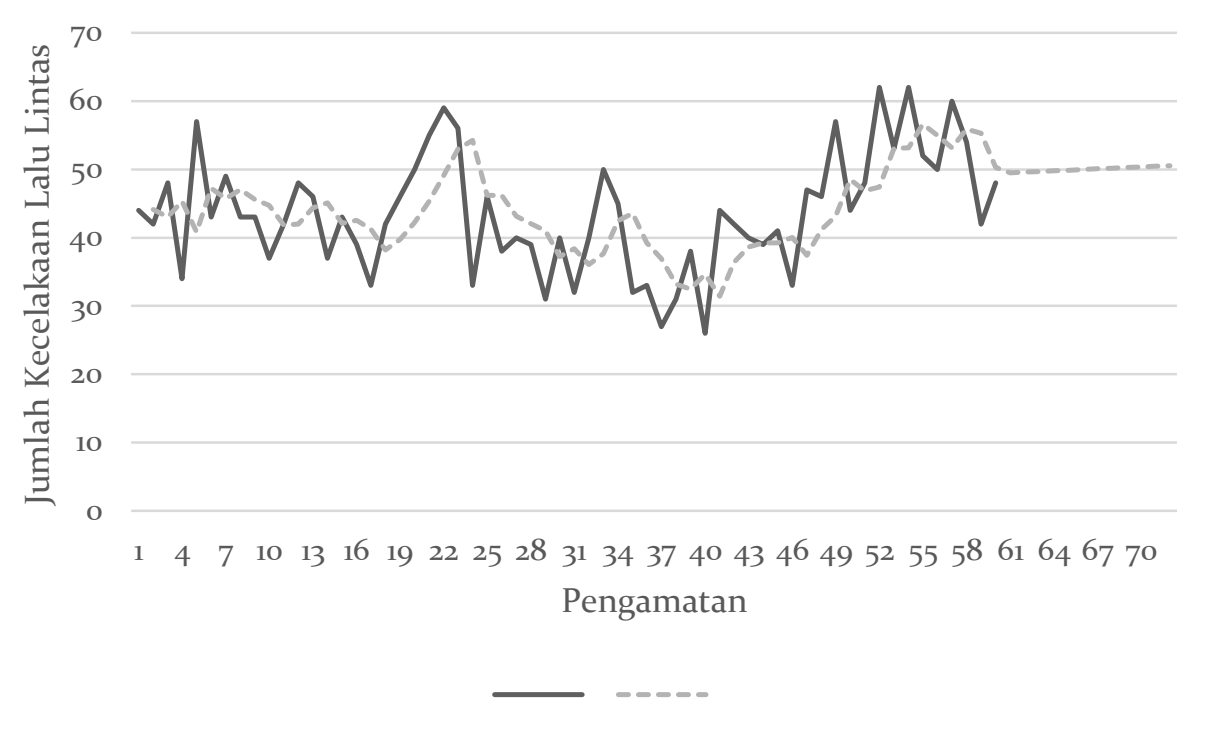

Gambar 4 Grafik Data Asli dan Peramalan Berdasarkan Model ARIMA (0, 1, 1)

Berdasarkan Tabel 5 dan Gambar 4 terlihat bahwa jumlah kecelakaan lalu lintas di Kota Pontianak selama satu tahun mendatang diperkirakan akan mengalami kenaikan. Kenaikan angka jumlah kecelakaan lalu lintas tersebut kemungkinan disebabkan oleh beberapa faktor seperti manusia, kendaraan, jalan, dan lingkungan.

\section{KESIMPULAN}

Berdasarkan hasil dan pembahasan diperoleh model terbaik untuk meramalkan jumlah kecelakaan lalu lintas yaitu model ARIMA $(0,1,1)$ dengan bentuk persamaannya $Z_{t}=0,95+Z_{t-1}+e_{t}-0,62 e_{t-1}$. Hasil verifikasi model ARIMA $(0,1,1)$ menunjukkan semua nilai error berada dalam batas pengendali serta nilai MAPE sebesar $14,88 \%$ yang artinya model ARIMA $(0,1,1)$ adalah model yang cukup baik untuk memprediksi jumlah kecelakaan lalu lintas Kota Pontianak dalam satu periode ke depan.

\section{DAFTAR PUSTAKA}

[1] Markidakis S, Wheelwright S.C dan McGee V.E. Metode dan Aplikasi Peramalan, Jilid I Edisi Kedua. Jakarta: Erlangga; 1992.

[2] Cryer J.D dan Chan K.S. Time Series Analysis. With Applications to R. January. New York: Springer Science Business Media, LLC, 2008.

[3] Azriati K.F, Hoyyi A dan Mukid M.A. Verifikasi Model ARIMA Musiman Menggunakan Peta Kendali Moving Range, Jurnal Gaussian. 2014;4(3):701-710, 2014.

[4] William W. Time Series Analysis, Second. December. United States: Greg Tobin, 2006.

[5] Montgomery D. Introduction To Statistical Quality Control. United States: John Wiley \& Sons, Inc, 2009.

[6] Kartika H. Analisis Pengendalian Kualitas Produk CPE Film Dengan Metode Statistical Process Control Pada PT . MSI. Jurnal Ilmiah Teknik Industri. 2013;1(1):50-58.

CANSERIA YULI ISMAYANTI $\quad$ : Jurusan Matematika FMIPA UNTAN

DADAN KUSNANDAR : Jurusan Matematika FMIPA UNTAN dkusnand@untan.ac.id

NURFITRI IMRO'AH : Jurusan Matematika FMIPA UNTAN nurfitriimroah18@gmail.com 